\title{
TÉRSZEMLÉLET-FEJLESZTÉST SEGÍTŐ FOGLALKOZÁSOK LEGO ESZKÖZÖK SEGÍTSÉGÉVEL
}

\author{
Szerzők: \\ Beták Norbert (PhD.) \\ Univerzita Konštantína Filozofa v Nitre \\ (Szlovákia) \\ Szabó Tibor (PhD.) \\ Univerzita Konštantína Filozofa v Nitre \\ (Szlovákia)
}

Első szerző e-mail címe:

nbetak@ukf.sk

\section{Lektorok:}

\author{
Illés Zoltán (dr. habil., PhD.) \\ Eötvös Loránd Tudományegyetem \\ (Magyarország) \\ Pšenáková Ildikó (PhD.) \\ Trnavská univerzita v Trnave \\ (Szlovákia)
}

...és további két anonim lektor

\begin{abstract}
Absztrakt
Tanulmányunk a térszemlélet fejlesztésének egy módszertani lehetőségét tárgyalja a 9-13 éves gyermekek tekintetében. Erre a célra a jól ismert Lego építőjátékot és annak digitális változatát alkalmazzuk. A tanulmány részletesen ismerteti a fejlesztő tevékenység egyes fázisait, mely a digitális és valós térben egyarán megvalósulva, részben a játékos mérnöki munka felé irányítja a tanulókat.
\end{abstract}

Kulcsszavak: térszemlélet, fejlesztés, Lego, informatika

Diszciplína: pedagógia

Abstract

ACTIVITIES SUPPORTING THE DEVELOPMENT OF SPATLAL SKILLS USING LEGO TOOLS

Our study discusses a methodological option for developing spatial skills for children aged 913 years. For this purpose, we have used the well-known Lego building game and it's digital tool. The study describes in detail the different phases of the development activity, which, realized in both digital and real space, partly leads the students towards the playful engineering work.

Keywords: spatial skills, development, Lego, informatics

Disciplines: pedagogy

Beták Norbert és Szabó Tibor (2020). Térszemlélet-fejlesztést segítő foglalkozások Lego eszközök segítségével. OxIPO - interdiszciplináris tudományos folyóirat, 2020/4, 71-81. doi: 10.35405/OXIPO.2020.4.71 
Számos szakma, illetve tevékenység említhető, amelyek végzése folyamán kiemelkedően fontos szerepet játszanak az egyén téri képességei. Példaként említhetünk néhányat, mint az építész, a tervező, a lakberendező, a sofőr, akinek gyakran ismeretlen helyen kell tájékozódnia, és még sorolhatnánk. Végül azt is mondhatjuk, hogy valamilyen módon szinte minden foglalkozásnál tudunk találni olyan problémát, melynek megoldása során a tárgyalt képességre szükség van, még ha az nem is tűnt eddig nyilvánvalónak. Emellett a mindennapi életünkben is nélkülözhetetlen a tárgyalt képesség. Nem mindegy viszont az, hogy az adott probléma hatékony megoldása milyen szintű téri képességet igényel. A továbbtanulás tekintetében a téri képességek magasabb szintjét például gyakran a mérnöki-, matematikai-, műszakitudományok követelhetik meg (például a STEM szakmák által igényelt tudományterületek). Például Rumanová (2020) szerint általánosan ismeretes, hogy a tanulók nem rendelkeznek megfelelő szintű térszemlélettel az oktatás bármely szintjét is tekintve. Emellett Nagy (2003) szerint a képességek fejlődése hosszú folyamat, éveket vesz igénybe. Nyilvánvaló, hogy az oktatási rendszer feladata lenne ezen képességek fejlesztésének a biztosítása.

Az egyéniség különböző képességekkel jellemezhető, amelyekre több felosztás is létezik. A felosztásokban a téri képességek is besorolást kapnak.
„A térszemlélet a térbeli geometriai alakzatok alakjairól, tulajdonságairól és kölcsönös kapcsolatairól szóló reprodukciós és prediktív, statikus és dinamikus elképzelésekhez kapcsolódó képességek összessége" (Molnár, 2004) Egy másik definíció szerint „a térszemléletet, a vizuális kép mentális generálásának, forgatásának és átalakításának képessége határozza meg" (Park, Lubinski és Benbow, 2010).

A kérdés az lehet, hogy milyen módon fejleszthetők leghatékonyabban a téri képességek.

Bábaly és Kárpáti (2015) szerint öt tevékenységtípus nevezhető meg, melyek a leghatékonyabban fejleszthetik a térszemléletet, mégpedig:

- építőjátékok használata gyermekkorban,

- kézmúves foglalkozások és barkácsolás,

- 3D-s számítógépes játékok,

- sportolás,

- matematikai képességek fejlesztése.

Nagy Lehocky (2000) szerint ,a különböző geometriai testek építése fejleszti a tanulók térbeli szemléletét és konstruktív képességét". Ezekre a tényekre hagyatkozva, mi is próbáltunk felépíteni, illetve megtervezni egy tevékenységet a fejlesztés céljából, alkalmazva a digitális- és valós teret egyaránt.

Továbbá fontos figyelembe vennünk a célcsoport korát is, például Hejný és tsai. (1990) szerint két időszak létezik, amelyik 
ideális a téri képességek fejlesztésére: 5-6 éves korban, 11-12 éves korban. Viszont az 5.-6. osztályban a térgeometriára a NAT által javasolt óraszám mindössze 16. Úgy gondoljuk, hogy ez az óraszám az adott korosztály esetében magasabb is lehetne. Másrészt itt lehetne figyelmet fordítani a térszemlélet multidiszciplináris jellegére, mivel szinte bármely tantárgyon belül megjelenthet, vagy különböző feladatokon keresztül „becsempészhető” a tantárgy tartalmába. Természetesen más korcsoportoknál is fejleszthetőek ezek a képességek, csak valószínűleg nem olyan látványos fejlődési szintugrással.

\section{Lego eszközök és a térszemlélet}

A térszemlélet fejlesztésének érdekében végzett tevékenységek gondos módszertani előkészületeket és alapos tervezést igényelnek. Manapság már könnyen hozzáférhető technikai-technológiai apparátus áll rendelkezésre a fejlesztő foglalkozások eredményességének biztosítása érdekében.

A népszerû virtuális környezetek is számos lehetőséget kínálnak többek közt például térbeli alakzatok megvizsgálására, különbözô testek forgatására, térbeli animációk készítésére, vagy akár különböző szerkezetek, épületek 3D vizualizációjára. Ugyanakkor a valós térben is fellelhetők olyan (segéd)eszközök, melyek kiváló lehetőségeket rejtenek a térbeli gondolkodás fejlesztésének segítésében - ezt a célt képesek szolgálni például a modellező készletek, építőjátékok, építőkockák stb. Mindezen lehetőségek megfelelő fejlesz- tő-módszertan mellett történő alkalmazása vitathatatlan, s nincs ez másként a célzott térbeli képességfejlesztés terén sem. A mentális képességek és az azokat támogató különböző tevékenységek aktív igénybevétele jelentheti a térszemlélet (és sok más egyéb képesség) fejlesztésének valódi, tartós előmozdítását.

A konstrukciós játékok térszemléletfejlesztő hatását több kutatás is alátámasztja. Dewar (2017) a konstrukciós blokkokat erôteljes oktatóeszközökként értelmezi, melyek segítségével könnyebben fejleszthetôk a:

- motorikus képességek,

- térszemlélet,

- kognitív rugalmasság,

- nyelvi készségek,

- kreatív, divergens gondolkodás,

- szociális kompetenciák,

- mérnöki képességek.

A következőkben röviden bemutatjuk azon eszközöket, melyeket a térszemlélet fejlesztésének érdekében használtunk. Külön kitérünk a Lego Digital Designer alkalmazásra, amely a virtuális környezetet biztosította a fejlesztésben részt vevő gyermekeknek. Továbbá, a fejlesztő foglalkozások során felhasználtunk még különböző típusú és formájú Lego építőelemeket, melyek az elkészített szerkezetek alapelemeiként szolgáltak.

\section{Lego Digital Designer}

Bakonyi és tsai. (2019) szerint ,mind a számítógépekkel, mind pedig az okostelefonokkal egy olyan eszközt kapott ke- 
zébe az emberiség, amely a hétköznapi feladatok megoldásának megkönnyítésére, információszerzésre, kommunikációra és szórakozásra is páratlan lehetőségeket ad’. Az ilyen eszközök által adta lehetőségek, illetve az eszközökhöz illeszkedő megfelelő szoftverek választása mellett, lehetőségünk nyílik akár virtuális Lego modellek készítésére is.

Több szoftver közül is válogathatunk. A legismertebb a Lego cég által fejlesztett Lego Digital Designer (LDD), említésre érdemesek lehetnek még a LeoCAD és a Studio nevű szoftverek. Az LDD szoftverről a továbbiakban bővebben is említést teszünk.

Az LDD alkalmazás futtatható az MS Windows operációs rendszereken (a Windows XP-től), ill. az OS X 10.10 verziótól kezdődően. Az 1. ábrán megte- kinthetjük az alkalmazói felületet, a felső főmenüsor klasszikus kialakítású.

A főmenü alatt levő sorban találjuk az eszköztárt, ahol is az eszközök olyan ikonokkal vannak ábrázolva, hogy az a gyermek, amely már ismeri a Lego építőjáték klasszikus változatát, intuitív módon, könnyedén elsajátítsa használatukat. Bal oldalt látható az építő paletta, ahol megtalálhatók az egyes építőelemek. Sok különböző építőelem létezik, ezek a sajátos tulajdonságaik szerint csoportosítva vannak, ezzel segítve a felhasználó munkáját. Az LDD három használati módot kínál a felhasználónak: építő mód (Build Mode), nézet mód (View Mode), építési útmutató mód (Building Guide Mode). Természetesen csak az általunk vélt legfontosabb lehetőségeket említettük.

\section{1. ábra: A Lego Digital Designer használat köz̧ben (forrás: a S zurző́k)}

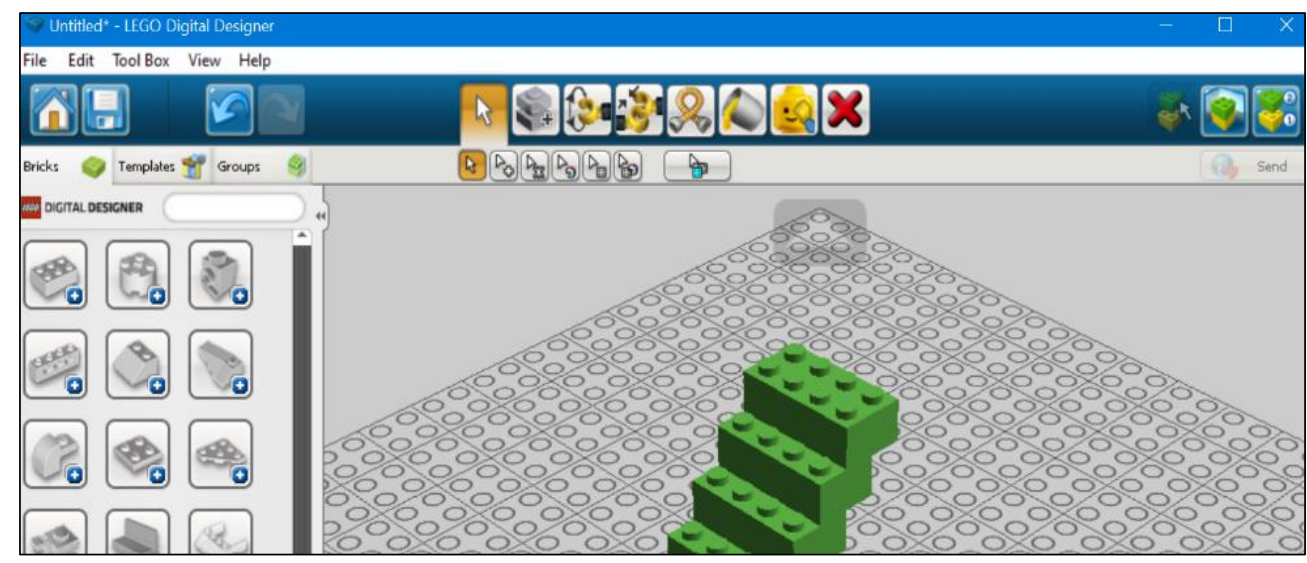


Fontos tulajdonságként említhető a készletfüggetlenség, azaz lehetőségünk van bármely elemet tetszőlegesen sokszor használni. Számunkra érdekesnek bizonyulnak a szerkesztés alatt álló vagy a már kész modellek forgatásának lehetőségei. Továbbá a közelítés lehetősége, mely akár azt is lehetővé teszi, hogy a nagyobb üreges modellt belülről szemléljük. Érdekes szemléleti módot nyújthat továbbá a Hide Tool lehetőség, mely segítségével elrejthető a modell egy része (a kijelölt elemek csoportja). Az említett eszközök különösen fontosnak tekinthetők a térszemlélet szempontjából, hiszen a modellt különböző szemszögből teszik a szemlélő számára „körbejárhatóvá”, illetve megtekinthetővé. Természetesen a DLL-t tekintve, csak olyan rövid jellemzést vázoltunk fel, mely az általunk vélt legfontosabb lehetőségeket mutatja be a következőben felvázolt tevékenységhez.

\section{Térszemléletet fejlesztő}

\section{foglalkozások a gyakorlatban}

A következőkben néhány olyan foglalkozást mutatunk be, melyek a térszemlélet fejlesztésének érdekében egy nyári tábor keretén belül kerültek alkalmazásra, kipróbálásra. Az alábbi példák gyakorlati megvalósításához szükségesek - a fentiekben említett - Lego építőelemek-építőkockák és az ingyenesen letölthető Lego Digital Designer szoftver. Az alább található foglalkozások a 9-13 éves korosztály számára alkalmazhatók voltak, viszont a számítógépes tervezést és vizualizációs feladatok megfelelőbbnek bizonyultak az említett korcsoport idősebb résztvevői számára.

A foglalkozások csoportos munka (3-4 fô) formájában valósultak meg, miközben minden egyes csoport ugyanazokat a feladatokat oldotta meg - csupán korosztály függvényében történt különböző típusú feladatok kiosztása. Az egyes foglalkozások előre meghatározott logikai sorrend alapján történtek. A létrejött tevékenységfázisok sorrendjét pedig az 1. táblázat szemlélteti.

Elmondható, hogy a feladatok megoldása során általában mind a négy tevékenységfázis megvalósult, néhány esetben, a feladat jellegéből adódóan maradt ki csupán egy-egy fázis, ill. a kérdezés fázis többször is ismétlődött.

\section{1. táblázat: Tevékenységfázisok leirással (forrás: a Szerzőo)}

\begin{tabular}{ll}
\hline Tevékenységfázis & Leírás \\
\hline Kérdezés & Fejlesztő kérdések megválaszolása \\
\hline Tervezés & Munkamenet megfogalmazása \\
& Munkamenet felvázolása \\
\hline Ötletelés \\
\hline Éítés & A modell kézi készítése \\
& A modell számítógépes -3D vizualizáció készítése \\
\hline Dokumentálás & Bemutató készítése \\
& Dokumentáció készítése \\
& Prezentálás a többi csoport előtt \\
\hline
\end{tabular}


Nagy Lehocky (2008) szerint „a feladatok optimális nehézségi foka is feltétele a motiváció és érdeklődés kialakításának". A folyamatos érdeklődés fenntartásának érdekében ezt a tényt próbáltuk szem előtt tartani az egyes feladatok nehézségi fokának optimális megválasztásával, illetve növelésével.

\section{Kérdezés}

A tevékenységek során a folyamatos visszacsatolást a rendszeres kérdésfelvetés biztosította. A kérdésfelvetés a foglalkozások végrehajtása mentén épült be a tevékenységfázisok (tervezés, építés, dokumentálás) során attól függően, hogy mikor és milyen esetleges problémával, megoldandó helyzettel szembesültek a gyermekek. Az ilyen, „helyzetből adódó kérdések" mellett előre elkészített kérdések is felvetésre-, majd megválaszolásra kerültek. Ezen fázis legnagyobb hozamát abban tapasztaltuk, hogy a kérdések újabb és újabb irányba terelték a gyermekek gondolatait, melynek eredményeként megváltoztak cselekedeteik, s így olyan összefüggésekre jöhettek rá, melyek az adott fejlesztési feladatoknál megalapozott fontosságúak lettek.

Az építő jellegú kérdések, melyek gyakran megoldandó probléma formájában fogalmazódnak meg, a gyermek feladatmegoldási folyamatának közben is előbukkanhatnak - ezeket is érdemes megfigyelni, megjegyezni és esetlegesen a többi gyermek felé is közvetíteni. A kérdések megválaszolását ezen kívül többször azonnali reakció követte, viszont a válasz helyességének igazolása érdekében el kellett végezni egy adott tevékenységet beállítani különböző paraméterértékeket, megváltoztatni az adott feltételeket, körülményeket, kipróbálni valamilyen tevékenységet egy eltérő környezetben, átépíteni az adott szerkezetet stb.

\section{Tervezés}

A tervezés fázisa kiváltképp fontos része a mérnöki munka lépéseit követő fejlesztő feladatmegoldásnak. Az építőkockák felhasználásával létrehozott szerkezetek előzetes-, gondos tervezést feltételeznek, főleg mivel valós környezetben épülő- és valós környezetben felhasználandó eszközökről van szó. Ilyen esetben pedig számos befolyásoló körülményt kell átgondolni és/vagy olyan környezeti jellemzőket kell megvizsgálni, mérlegelni, majd figyelembe venni, melyek az adott szerkezet funkcionalitása szempontjából lényegesek lehetnek. A tervező munka számítógépes megvalósítását a Lego Digital Designer szoftver segítségével végezték a gyermekek (lásd: 2. ábra). Ennek nagy előnye, hogy komplex 3D vizualizáció elkészítésére alkalmas, s így a felhasználók térbeli forgatást is végezhetnek - lehetővé téve az adott szerkezet alaposabb megvizsgálását és későbbi valós környezetben történő kialakítását.

A térlátás fejlesztésének elősegítéséhez kiváltképp fontos lehet az olyan feladatok elvégzése, melyek során az absztrakt el- 
2. ábra: Az LDD rendsz̨erben elkészített szerkęet (forrás: a Sz̨erzőo)

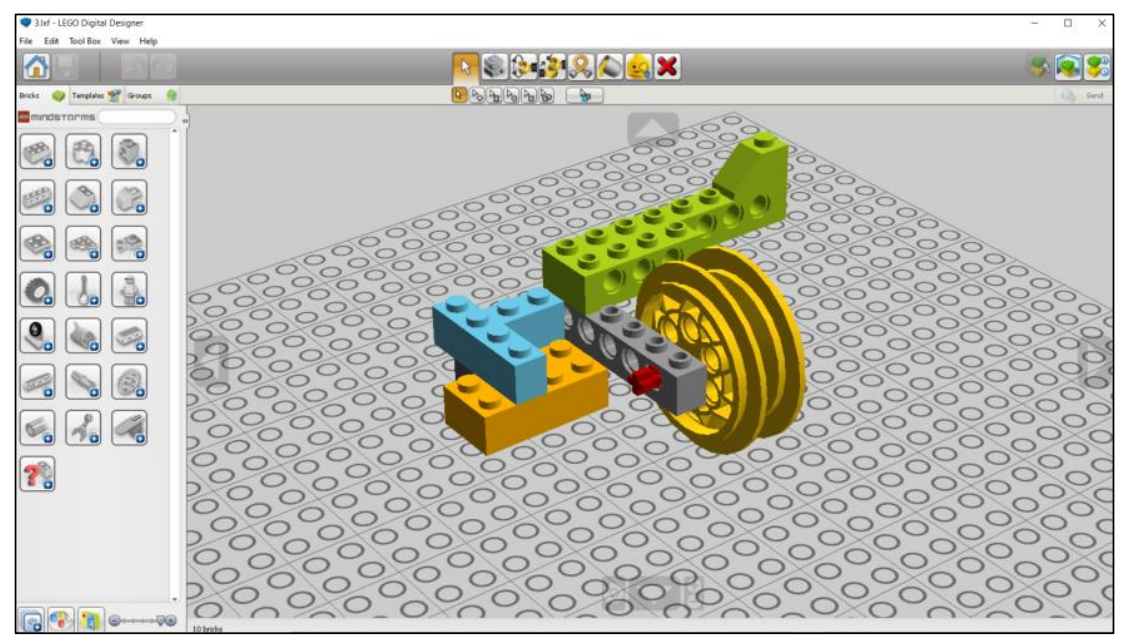

képzelést valós, ún. „kézzelfogható” formában kell bemutatni. Ilyen feladatok lehetnek többek közt azok, melyek egy adott feladat elvégzésére alkalmas Legoszerkezet kitalálását, megtervezését követelik, majd az ötlet, elképzelés alapján a 3D vizualizáció elkészítését is feltételezik. $\mathrm{Ez}$ a folyamat viszont fordított sorrendben is megvalósítható, ami azt jelenti, hogy egy adott Lego-szerkezet utólagosan kerül megrajzolása, megtervezésre akár kézi vagy számítógépes eszközök segítségével.

Az ilyen és ehhez hasonló tevékenységek során a gyermek lehetőséget kap többek közt arra, hogy:

- a síkban „érvényesülő” tárgyak, eszközök térbeli megfelelőjét elkészítse,
- a térbeli alakzatok kétdimenziós vetületét megrajzolja,

- az alakzatok forgatásával különböző nézetek táruljanak elé, melyek alkalmat biztosítanak arra, hogy az eltéréseket és azonosságokat felismerje,

- a tervezés különböző fázisainak megismerését és gyakorlását megvalósítsa,

- komplex módon fejlessze olyan képességeit (kreativitás, térszemlélet, problémamegoldás, kritikai gondolkodás stb.), melyek további élete során a lehetô legnagyobb bizonyossággal szükségesek lehetnek.

\section{Építés}

Az óvodás- és iskoláskorú gyermekek konstruktív és kreatív gondolkodásának 
fejlesztésére számos háromdimenziós modellépítő eszköz áll rendelkezésre. A játékos környezetben és szórakoztató feladatok mentén történő tevékenységek nem csupán lefoglalják a gyermekeket, de számos, nagyon hasznos készség fejlesztésére is alkalmasak. A szociális készségektől kezdve, egészen a motorikus képességeken át eljuthatunk akár a természettudományos megközelítés és gondolkodásmód játékos gyakorlásáig - felkelthetjük és koncentrálhatjuk a gyermekek érdeklődését az ún. STEM (Science, Technology, Engineering, Mathematics) területek irányába. A modellezési és építési foglalkozások során a gyermekek olyan alkotó tevékenységet végeznek, melynek kulcsfogalma a megvalósítás és lényege a tapasztalati tanulás (lásd: 3. ábra).
A megvalósítás mozgatórugója az az ötlet és kreativitás, mely a lehetőségek és feltételek tükrében dinamikus megoldásokat hoz létre. A tapasztalati tanulás folyamata pedig az elméleti tudás gyakorlati alkalmazását jelenti és természetesen az abból fakadó új ismeretek, összefüggések és következtetések felismerését és megértését tűzi ki célul.

A térszemlélet fejlesztésének szempontjából fontosnak tartjuk, hogy a gyermekek megismerjék (megtapintsák, elforgassák stb.) azokat az építőelemeket, melyek majd a létrehozandó szerkezetek alkotóelemeivé válnak. Tapasztalataink alapján gyakori esetként említhetjük, hogy egy létrehozott konstrukció utólagos változtatásokat igényel, s ilyenkor a térbeli látásmód fontossága is felértékelődik, ugyanis például a szerkezeti kialakítás megkövetelheti a méretek, formák igazodását.

3. ábra: Alkotó, konstrukciós tevékenység a foglakozások közben (forrás: a Szerzőo)

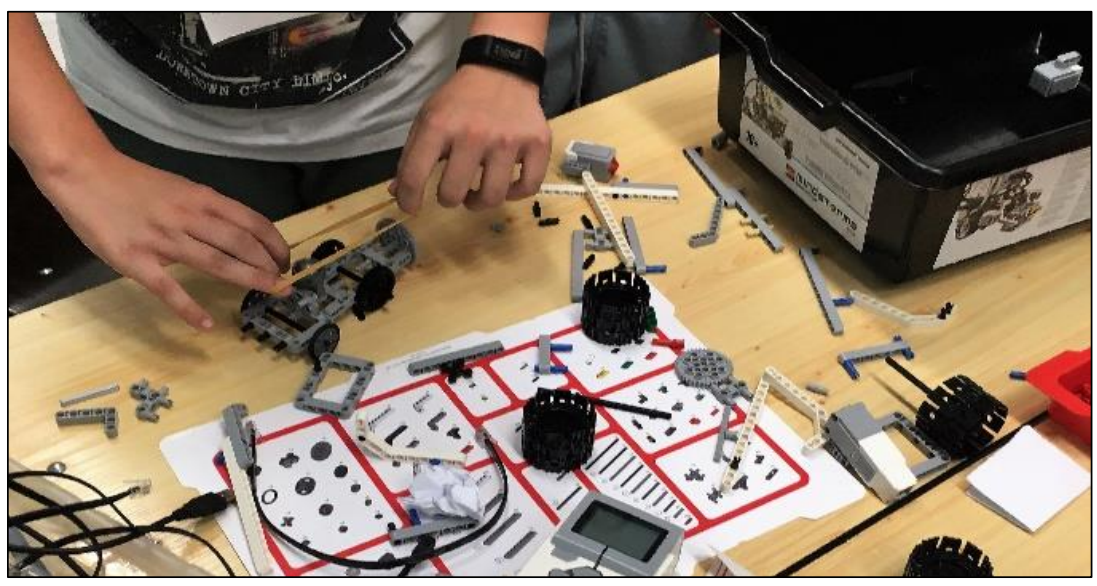


Továbbá, fontosnak tartjuk, hogy a gyermekek megtapasztalják a virtuális közegben kialakított szerkezet valóskörnyezeti jellemzőit, tulajdonságait.

Ez a virtuális (3D) térből valós (3D) térbe történő ,átjárás” folyamata hozzájárulhat a további tervezési feladatok minőségéhez, javíthat a reális térlátás szintjén, de fontossága megmutatkozik a konkrét konstrukciós feladatok elvégzésénél is (például egy konstrukció zárt részében lévő térbeli elhelyezkedés felmérése).

\section{Dokumentálás}

A foglalkozások során végzett Dokumentálás folyamata, nem csupán a tényleges dokumentáció elkészítését jelentette, hanem a munkavégzés folyamatának leírását és a többi csoport előtti bemutatását egyaránt. Ez a rész (tevékenységfázis) föleg a kommunikációs és kollaboratívegyüttműködő képességek kialakításában, fejlesztésében játszik szerepet, viszont az ismeretek és tapasztalatok összegzésének céljából is fontosnak tartottuk. Továbbá, mivel csoportfoglalkozások keretén belül történt a feladatmegoldás, így az egyes csoporttagok esetenként különböző részfeladatok megoldásán dolgozhattak, s így indokolttá vált, hogy a munkavégzés zárásaként összegezzék és elmagyarázzák társaiknak az esetleges megoldások menetét és akár a felmerült problémákra is felhívják a figyelmüket. A dokumentáció elkészítése során az egyes lépések rendszerezése - logikai sorrendjének szemléltetése volt a fó cél, illetve ezek megbeszélése csoporton belül, valamint prezentálása a többi csoport előtt. A dokumentációkészítéshez használhatók voltak számítógépes eszközök, de papír és ceruza, fényképezőgép egyaránt. Gyakori esetként mutatkozott meg, hogy a gyermekek az elkészítés menetét saját okostelefonjuk segítségével is megörökítették és/vagy az elkészített szerkezet különböző nézeteinek fényképeivel is szemléltették a saját dokumentációjukon belül (lásd: 4. ábra).

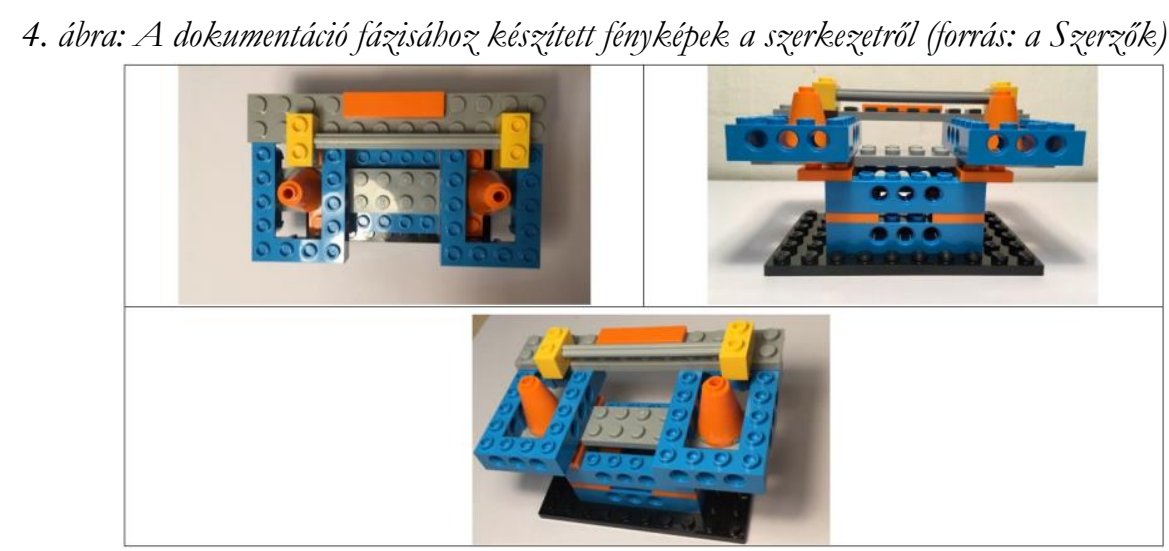




\section{Konklúziók}

A térbeli gondolkodás és a téri képességek a mindennapi élet számos területén nyújthatnak segítséget és biztos támaszt, sőt különböző problémamegoldást igénylő szituációkban akár elengedhetetlenek is lehetnek. A térbeli gondolkodás három funkciót szolgál (2006, NRC): (1) leíró funkció, amely rögzíti, megőrzi és közvetíti a tárgyak megjelenését és viszonyait; (2) analitikai funkció, amely lehetővé teszi a tárgyak szerkezetének megértését; és (3) következtetési funkció, amely válaszokat generál az objektumok evolúciójával és működésével kapcsolatos kérdésekre.

Tanulmányunk olyan foglalkozássorozatot mutat be, amely illeszkedik az előbbi rendeltetésekhez, funkcióhoz és gyakorlati tapasztalatokra épül. A létrehozott-, téri képességek tartományára irányuló fejlesztőgyakorlatok négy tevékenységfázis ciklikus ismétlésével valósultak meg, így biztosítva, hogy különböző egyéb területek is érvényesülést kapjanak (például kommunikációs készségek, együttműködési képességek stb.) A foglalkozások a kérdezés-tervezés-építés-dokumentálás fázisain keresztül haladva olyan játékos feladatokat tártak az általános iskolás gyermekek elé, melyek digitális eszközök- és valós, térbeli alakzatok felhasználását egyaránt igényelték. Az előbbi kialakítás követte, többek közt, azon megállapítást, mely szerint a kétdimenziós tevékenységeknél hatásosabban fejlesztenek a valós térben végzett műveletek: az építés, a konstruálás, a téri mozgásformák (Séra, Kárpáti és Gulyás 2002). Tapasztalataink alapján elmondható, hogy a komplex, problémamegoldást feltételező feladatok felkeltették a gyermekek érdeklődését. Nem elhanyagolandó azonban az a megfigyelésünk sem, mely szerint előtérbe kerültek a természettudományos összefüggések keresési és értelmezési mechanizmusai. A gyermekeknél jellemző volt az ok-okozati viszonyok megállapítása is. A fentiekben leírt foglalkozásokat pilot-programnak tekintjük, amely következő kutatási és fejlesztési terveink megalapozásához járul majd hozzá. A bemutatott foglalkozásokat egy 9-13 éves gyermekekből álló csoportban már kipróbáltuk, a jó tapasztalatok révén további felhasználásra ajánljuk gyakorló pedagógusok számára, illetve további pedagógiai kutatások elvégzéséhez is.

\section{Köszönetnyilvánítás}

Jelen tanulmány a KEGA 015UKF4/2020 Development spatial abilities of 10-12-year-old students pályázat keretében jött létre.

\section{Irodalom}

Babály, B. és Kárpáti, A. (2015) A téri képességek vizsgálata papír alapú és online tesztekkel. Magyar Pedagógia, 115. (2.) pp. 67-92. doi 10.17670/MPed.2015.2.67

Bakonyi, V., Illés, Z., Pšenáková, I. és Heizler, A. (2019) Smart eszközök a 
tanórákon. In: InfoDidact 2019, Zamárdi, Mad’arsko, pp. 21-30.

Beták, N. (2019). A robotika, mint a 21. századi készségek fejlesztésének eszköze. Pedagógiai változások - a változás pedagógiája. pp. 491-498.

Hejný et al. (1990) Teória vyućovania matematiky 2. Bratislava: Slovenské pedagogické nakladatel'stvo

Juliá, C. és Antoli, O. (2015). Spatial ability learning through educational robotics. International Journal of Technology and Design Education. pp. 185203.

Kerettanterv az általános iskola 5-8. évfolyama számára: Matematika (2020). Web: https://www.oktatas.hu/pub_bin/dlo ad/kozoktatas/kerettanterv/Matemati ka_F.docx

Krištofová Z. (2014). Digitálne lego. Metodicko-pedagogické centrum v Bratislave, Bratislava. Letöltés: 2020.11.01. Web: https://mpcedu.sk/sites/

default/files/publikacie/z kristofova digitalne lego.pdf.

Molnár, J. (2009) Rozvijeni prostorové predstavivosti (nejen) ve stereometrii.
Univerzita Palackého v Olomouci: Olomouc.

Nagy, J. (2003) Az eredményesebb képességfejlesztés feltételeiről. Iskolakultúra, 13 (8) pp. 40-52.

Nagyová Lehocká, Z. (2008) A tanulói érdeklődés felkeltésének fontossága. In: Képrés és gyakorlat: tanulmánykötet. Nitra, UKF. pp. 33-37.

Nagyová Lehocká, Z. (2020) Manipulációs eszközök a matematikaórán. In: Katedra: Szlovákiai magyar pedagógusoke és szülök lapja. 28, (2) pp. 26-27. x, Washington, D.C.

Rumanová, L. (2020) Bádatel'ská aktivita vo vyučovaní geometrie na základnej škole a postrehy učitel'ov $\mathrm{k}$ danej aktivite. In: Acta Mathematica Nitriensia. 6 (2) pp. 18-23. doi 10.17846/AMN.2020.6.2.18-23.

Séra L., Kárpáti A. és Gulyás J. (2002). A térszemlélet. A vizuális-téri képességek pszichológiája, fejlesztése és mérése. Comenius Kiadó, Pécs.

Tóth, P. (2013). A téri múveleti képességek fejlettségének vizsgálata. Vqdelávanie, výskum a metodológia. pp. 285-294. (Letöltés: 2020.11.01.) (Web: http://www.irisro.org/pedagogia2013j anuar/0402TothPeter.pdf) 